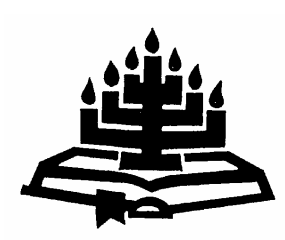

\title{
1 Timoteus 2:8-12 - voorskrifte vir gedrag in die erediens, in die gewone lewe of in die huwelik? 'n Eksegetiese studie
}

\author{
Douw G. Breed \\ Skool vir Bybelwetenskappe en Bybeltale \\ Potchefstroomkampus \\ Noordwes-Universiteit \\ POTCHEFSTROOM \\ E-pos: dbreed@telkomsa.net
}

\begin{abstract}
1 Timothy 2:8-12 - a code of conduct for public worship, ordinary life or marriage? An exegetic study

Throughout the world, the relation between men and women are currently in the spotlight. In 1 Timothy 2:8-15, Paul gave instructions to men and women that may illuminate the relation between the sexes. This article attempts to clarify Paul's instructions to men and women. The article investigates whether Paul gives any indications in 1 Timothy 2:1-12 of whether his instructions are intended to regulate the conduct of both sexes during public worship, in ordinary life or in marriage. First, the study examines whether, in this letter, Paul gives any explicit indications of the context in which these instructions should be read. Next, it investigates Paul's indications in his instructions for prayer (v. 1-8), decoration (v. 8-9), learning, teaching and the wielding of authority (v. 11-12). Many scholars are convinced that this passage was aimed at people's conduct during public worship, but this study argues that Paul's instructions could also refer to people's conduct in ordinary life or marriage.
\end{abstract}

\section{Opsomming}

1 Timoteus 2:8-12 - voorskrifte vir gedrag in die erediens, in die gewone lewe of in die huwelik? 'n Eksegetiese studie

Die verhouding tussen mans en vroue is tans wêreldwyd in die kollig. Paulus gee in 1 Timoteus 2:8-12 aan mans en vroue voorskrifte wat lig kan werp op die verhouding tussen die twee geslagte. In hierdie artikel word gepoog om duidelikheid te kry 
oor die voorskrifte wat Paulus aan mans en vroue gee. Daar word nagegaan of Paulus in 1 Timoteus 2:1-12 enige aanduidings gee of hy in dié gedeelte na mans en vroue se gedrag in dié erediens, die gewone lewe of in die huwelik verwys. In hierdie ondersoek word eerstens aandag gegee of Paulus in dié gedeelte enige uitdruklike aanduidings gee van die konteks waarbinne die voorskrifte verstaan moet word. Daarna word ondersoek ingestel na die aanduidings wat hy in die voorskrifte vir gebed (v. 1-8), vir versiering (v. 8-9) en vir leer, onderrig en gesag uitoefen (v. 11-12) bied. Hoewel die meeste skrywers oortuig is dat Paulus in dié gedeelte oor gedrag in die erediens handel, word in hierdie artikel bevind dat dit ook moontlik is dat hy oor gedrag in die gewone lewe of die huwelik handel.

\section{Inleiding}

Die meeste skrywers (vgl. byvoorbeeld Barnett, 1989:225; Cairns, 1995:151; Guthrie, 1978:69; Howard, 1983:39-40; Osiek \& Balch, 1997:121) aanvaar dat die voorskrifte in 1 Timoteus 2:8-15 binne die konteks van die erediens 1 verstaan moet word. Hugenberger (1992:342-345) en Holmes (2000:300) wys egter daarop dat dit nie so vanselfsprekend is dat die skrywer werklik in hierdie gedeelte oor mans en vroue se gedrag in die erediens handel nie. Hugenberger poog om aan te toon dat daar in 1 Timoteus 2:9-15 na gedrag in die huwelik verwys word en hy wys op die ooreenkomste tussen 1 Timoteus 2 en 1 Petrus 3 . Volgens Holmes ${ }^{2}$ handel die skrywer in 1 Timoteus 2:8-12 oor die gedrag van mans en vroue in die algemene lewe en nie oor gedrag in die erediens nie.

Omdat die verhouding tussen mans en vroue en veral die gesagsverhouding tussen die twee geslagte tans wêreldwyd in die spervuur staan, en omdat Paulus ${ }^{3}$ in hierdie gedeelte juis hierdie sake aan die orde stel, is dit van groot belang dat die betekenis van hierdie gedeelte vir die hedendaagse mens nagegaan word. Wie

$1 \quad$ Vir 'n meer volledige bespreking van die erediens in die vroeë kerk, vergelyk Cullman (1953:7-120), Hahn (1973:6-108) en Moule (1964:9-81).

2 Vgl. ook Schottroff (1995:69-70).

3 Mounce (2000:xlviii-cxxix) wys daarop dat die besware wat skrywers teen Paulus se outeurskap uitlig, hoofsaaklik van historiese, teologiese en literêre aard is. Hy gee volledig aan hierdie besware aandag en toon oortuigend aan dat met groot vrymoedigheid aanvaar kan word dat 1 Timoteus deur Paulus geskryf is. Ook studies van Guthrie (1979:15-31) en Ridderbos (1967:14-32) dui aan dat die besware teen Paulus se outeurskap nie werklik gegrond is nie. 
egter na die betekenis van die gedeelte vra, sal duidelikheid moet kry oor die konteks waarbinne die voorskrifte in hierdie gedeelte verstaan moet word. Die doel van hierdie artikel is om juis na hierdie konteks ondersoek te doen. Die ondersoek word toegespits op die vraag of die voorskrifte in 1 Timoteus 2:8-12 enige aanduiding bied van die konteks waarbinne die voorskrifte verstaan moet word. In verdere studies behoort die lig wat die motiverings wat Paulus in 1 Timoteus 2:13-15 asook die breër tekstuele konteks van 1 Timoteus op die voorskrifte werp, aandag te kry.

Nadat daar in die artikel 'n uiteensetting gegee is van 'n moontlike gedagtestruktuur 4 van 1 Timoteus, word daar eerstens nagegaan of Paulus in dié gedeelte enige uitdruklike aanduidings gee van die konteks waarbinne die voorskrifte in die gedeelte verstaan moet word. Daarna word ondersoek ingestel na die moontlikheid dat daar uit die voorskrifte in 1 Timoteus 2:8-12 afgelei kan word watter konteks Paulus in 1 Timoteus 2:8-15 in gedagte gehad het. Ten slotte word 'n aantal gevolgtrekkings met betrekking tot die konteks waarbinne die opdragte in 1 Timoteus 2:8-15 verstaan moet word, gemaak.

\section{2. 'n Moontlike gedagtestruktuur van 1 Timoteus}

Om 'n uiteensetting van 'n gedagtestruktuur van 1 Timoteus te gee, is die volgende sake nagegaan: die ooreenkomste tussen 1 Timoteus en die antieke Griekse briefvorm, die aanduidings wat die mikrovlak van retoriese struktuur in 1 Timoteus 2 ten opsigte van die gedagtestruktuur van die brief bied en die doel van die skrywe, soos dit deur die skrywer in 1 Timoteus $2: 3-7 ; 2: 18-20$ en 3:14-16 aangedui word. Daar is nie in hierdie artikel ruimte om hierdie ondersoek weer te gee nie en daarom word slegs die resultate van die ondersoek weergegee. Die volgende uiteensetting sou as 'n aanduiding van die gedagtestruktuur van 1 Timoteus kon dien:
$1: 1-2$
Die aanhef
$1: 3-20$
Die opdrag aan Timoteus
$2: 1-6: 2 a$
Betaamlike optrede van mense wat tot God se huisgesin behoort teenoor die leer en gedrag wat die vals leraars voorgestaan het

\footnotetext{
$4 \quad$ Ten opsigte van die gedagtestruktuurontleding word aangesluit by die metode hiervoor wat deur Coetzee (1988:19-37) ontwikkel is en verder uitgebou is deur Breed (1994:45-76).
} 

$6: 2 b-19$
Finale opdragte
$6: 20-21$
Briefslot

Die gedagte-eenheid waarbinne 1 Timoteus 2 voorkom, te wete 2:1$6: 2 \mathrm{a}$, sou soos volg in kleiner gedagte-eenhede uiteengesit kon word:
2:1-15
Gedrag van gelowiges
$3: 1-13$ Gedrag van ouderlinge en diakens
$3: 14-16$ Die doel van die brief: die gedrag van God se huisgesin
$4: 1-14$ Die leer en gedrag van die vals leraars
$5: 1-6: 2 a$ Gedrag van verskillende groepe binne die kerk.

\section{Uitdruklike aanduidings in 1 Timoteus 2 van die konteks waarbinne die voorskrifte in dié gedeelte verstaan moet word}

Wanneer 1 Timoteus 2 in die 1983-Afrikaanse vertaling van die Bybel (vgl. Bybel, 1983) gelees word, blyk dit duidelik dat Paulus in hierdie gedeelte oor gedrag in die erediens handel. In 2:11 lui die vertaling: "' $n$ Vrou moet in die erediens stil en onderdanig wees en haar laat leer." Die volgende vers is vertaal: "Ek laat haar nie toe om daar onderrig te gee ...". Dit is duidelik dat "daar" na die voorafgaande "in die erediens" verwys. Wanneer hierdie vertaling egter in die beskikbare grondtekste van 1 Timoteus nagegaan word, blyk dit dat die woorde "in die erediens" nie in enige van die tekste voorkom nie. Dit is duidelik dat die uitdruklike verwysing na die erediens in die vertaling op 'n spesifieke interpretasie van die vertalers berus.

Hugenberger (1992:351) sê dat die skrywer se gebruik van die woorde a jh $r$ in 2:8 en g unh in 2:9-15 uitdruklik daarop wys dat hy in dié gedeelte voorskrifte vir die huwelik gee. Uit Louw en Nida (1988a:109, 119) blyk dit egter dat gunhvin sowel die semantiese veld Mense, vir die betekenis van 'n volwasse vroulike persoon van hubare ouderdom gebruik kan word as in die semantiese veld Familieterme, vir die betekenis van ' $n$ vrou wat met ' $n$ man getroud is. Louw en Nida (1988b:19) laat ook blyk dat die woord a jh v vir sowel 'n getroude as ongetroude man gebruik kan word.

By die nadere bestudering van 1 Timoteus 2 is dit duidelik dat Paulus nie enige uitdruklike aanduiding gee van die konteks waarbinne die voorskrifte in hierdie gedeelte verstaan moet word nie. 


\section{Die voorskrifte vir gebed in 1 Timoteus 2}

Paulus gee in 2:1-2 en in 2:8 voorskrifte vir gebed. Hierdie voorskrifte word nou nader ondersoek.

\subsection{Voorbidding vir alle mense, konings en almal wat hooggeplaas is (1 Timoteus 2:1-2)}

Volgens 1 Timoteus 2:1-2 dring Paulus daarop aan dat vir alle mense, konings en hooggeplaastes smekinge, gebede, voorbedes, dankseggings (dehsei" pros euca", ent euxei" eufaristia") gedoen moet word. Skrywers soos Mounce (2000:77), Ridderbos (1967:69-72) en Schreiner (1995:113) aanvaar dat die skrywer met hierdie opdrag een van die vroeë kerk se liturgiese handelinge tydens die erediens in die oog het. Hierdie aanname word egter nie werklik deur die skrywers gemotiveer nie. Kelly (1972:60) poog wel om 'n verband te lê tussen die woord euf́aristia in 2:1 en die Nagmaalviering. Volgens hom verwys die woord euf arist ia soos in 1 Korintiërs 14:16 moontlik na die Nagmaalviering. Kelly se aanname is ongegrond. Dit is eerstens nie duidelik dat Paulus wel in 1 Korintiërs 14:16 met die woord euf a r is t i a na die Nagmaalviering verwys nie (vgl. Grosheide, 1976:326). Tweedens moet daarop gelet word dat Paulus in 1 Timoteus 4:3 die woord euf arist ia gebruik om die dankgebed van gelowiges aan te dui. Dit is dus meer korrek om te aanvaar dat Paulus in 2:1 na danksegging in die gelowiges se gebede verwys. Omdat gebede 'n belangrike plek in die liturgie van die vroeë eredienste ingeneem het (vgl. byvoorbeeld Hand. 2:42), is dit inderdaad moontlik dat Paulus in 2:1-2 na gebede in die erediens verwys. Uit gedeeltes soos Filippense 4:6 blyk dit egter dat die gebede van gelowiges in die gewone lewe ook baie hoog geag is en dit is dus moontlik dat Paulus in 2:1-2 die gelowiges oproep om in hulle gebede (buite die erediens) voorbidding te doen.

\subsection{Voorskrifte vir mans se gebede (1 Timoteus 2:8)}

Paulus sê in vers 8 dat mans op elke plek (ej pant i; t op w) heilige hande moet opsteek. Schreiner (1995:113) en Verner (1983:372) glo dat en pant i; t op w na plekke verwys waar daar vir eredienste vergader is. Volgens hierdie interpretasie sou Paulus dus na die gebede wat mans tydens eredienste gebid het, verwys. Dit is egter duidelik dat die frase ej pant i; t op w nie noodwendig na plekke van aanbidding verwys nie. Daar moet dus uit ander gegewens afgelei word waarna Paulus met hierdie frase verwys. 
Dibelius en Conzelmann (1972:45) en Towner (1989:205-206) poog om 'n verband te lê tussen die woorde ej pant $i$; t opw en die

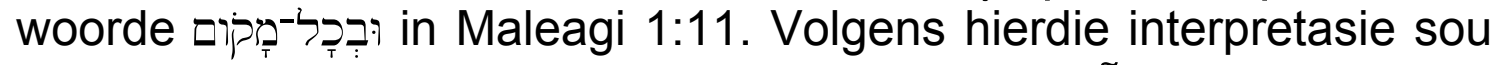
die skrywer met die woorde ej panti; top w die universele aanroeping van God, wat in Maleagi 1 ter sprake is, na vore wil bring. Sowel Mounce (2000:107-108) as Guthrie (1978:74) wys daarop dat Paulus hierdie frase dikwels gebruik (vgl. 1 Kor. 1:2; 2 Kor. 2:14 en 1 Tes. 1:8) en dat 'n verband tussen 1 Timoteus 2:8 en Maleagi 1 baie onwaarskynlik is. Dit blyk dus dat daar nie uit die gebruik van die woorde ej pant $i$; $t$ op w afgelei kan word dat Paulus noodwendig in 1 Timoteus 2:8 oor mans se gebede in die erediens handel nie.

Dit is belangrik om daarop te let dat die woord t opo" nie altyd gebruik word om plek of gebied aan te dui nie. Louw en Nida (1988a:513) toon aan dat die woord t op o" ook in die semantiese veld Doen gebruik kan word en wel vir die betekenis, ' $n$ rol wat aktiwiteit en verantwoordelikheid inhou (vgl. byvoorbeeld Hand. 1:25). Paulus sou dus met pant i; t op w/na "elke posisie van diens" of "elke verantwoordelikheid" kon verwys. Indien ej pant i; t op w/as bywoordelike kwalifikasie by epaironta" geneem word, sou 2:8 soos volg vertaal kon word: "Ek wil dat mans moet bid terwyl hulle ten opsigte van 5 elke verantwoordelikheid heilige hande ophef sonder toorn of twis." Indien t op o" so verstaan word, dui Paulus in 2:8 ' $n$ verband aan tussen die verantwoordelikhede wat mans het en hulle gebede. Wanneer mans bid, moet hulle sorg dat hulle ten opsigte van elke verantwoordelikheid rein hande het. Mans moet ten opsigte van hulle verantwoordelikhede gereinig wees van sondige dade. Die dade waarvan hulle gereinig moet wees, is waarskynlik die "toorn en twis" wat in 2:8 vermeld word. Wanneer hierdie interpretasie aanvaar sou word, blyk dit moontlik te wees dat Paulus die verantwoordelikhede van mans in die gewone lewe óf in die huwelik in 2:8 ter sprake bring. Paulus sou dan beklemtoon dat mans moet sorg dat daar nie ten opsigte van hulle verantwoordelikhede in die gewone lewe of ten opsigte van hulle verantwoordelikhede in die huwelik toorn en twis voorkom nie. Voordat mans dus bid, moet hulle ten opsigte van hierdie verantwoordelikhede enige toorn en twis uit die weg ruim.

5 Vergelyk Louw en Nida, (1988a:778) vir die betekenis waarvoor t op o" volgens hierdie interpretasie gebruik word. 


\subsection{Gevolgtrekking}

Dit is uit die voorgaande duidelik dat die voorskrifte vir gebede in 1 Timoteus 2 nie werklik ' $n$ aanduiding gee binne watter konteks 1 Timoteus 2:8-15 verstaan moet word nie.

\section{Voorskrifte vir die versiering in 1 Timoteus 2:9-10}

Paulus se opdragte in 2:9-10 aangaande die wyse hoe vroue hulleself moet versier, word deur verskeie eksegete (Kelly, 1972:6667; Verner, 1983:168-169) sonder werklike motivering as versiering vir die erediens verstaan. Mounce (2000:108), Guthrie (1978:74), De Kruijf (1966:40), Ridderbos (1967:80) en Roloff (1988:126) wys daarop dat dit as gevolg van die klem op goeie werke in hierdie verse problematies is om die opdrag aangaande versiering in verse 9-10 net op die erediens te betrek. Tog neem hulle aan, op grond van hulle oortuiging dat die skrywer in die onmiddellike konteks oor die erediens handel, dat versiering vir die erediens wel in 2:9-10 ter sprake is. Roloff (1988:126) sê: "Bezug auf den Gottesdienst allein durch den Kontext gesichert wird". Die feit dat Paulus "goeie werke" $(2: 10)$ met "vlegsels of goud of pêrels of kosbare klere" (2:9) kontrasteer, dui aan dat hy met sy voorskrifte vir versiering in 1 Timoteus 2:9-10 'n breër konteks as die erediens in die oog het. Hierdie goeie werke sou na optrede in die gewone lewe kon verwys, maar sou moeilik na gedrag binne die erediens kon verwys. Die feit dat 'n breër konteks as die erediens in 2:9-10 ter sprake is, beklemtoon die belangrikheid dat daar nie, soos dikwels gedoen word, sonder werklike gronde aanvaar kan word dat die ander voorskrifte in 2:8-15 op die erediens betrekking het nie.

Dit is duidelik dat die opdragte in 2:9-10 as voorskrifte kan dien vir die wyse hoe vroue hulle in die daaglikse lewe moet versier. Dit is egter vir die doeleindes van hierdie artikel belangrik om te vra of die voorskrifte wel ook met die huwelik verband kan hou. Paulus sê dat vroue se versiering onder andere met beskeidenheid (aijou") en ingetoënheid (s wf ros unh") gepaard moet gaan. Verskeie skrywers (vgl. byvoorbeeld Groenewald, 1977:36; Kelly, 1972:66 en Mounce, 2000:109) wys daarop dat altwee die woorde a i dou 'en s wf ros unh" met die seksuele verband kan hou. Aidou" kan op terughoudendheid ten opsigte van seksuele sake wys en s wf ros unh " op selfbeheersing op seksuele gebied. Hiervolgens verwag Paulus dus van vroue om hulle nie seksueel verleidend te versier nie. Paulus sou hierdie vereiste sekerlik vir alle gelowige vroue kon stel. Indien hy in 2:8-15 oor gedrag in die huwelik handel, sou hy egter ook 
spesifiek van getroude vroue kon verwag om hulle nie seksueel verleidend te versier nie (vgl. 1 Pet. 3:1-5).

Uit die voorafgaande is dit duidelik dat dit moontlik is dat die skrywer in 2:9-10 vir alle gelowige vroue wil aandui hoe hulle hul in die gewone lewe behoort te versier, of dat hy spesifiek wil aandui hoe getroude vroue hulle behoort te versier. Die feit dat 'n breër konteks as die erediens in 2:9-10 ter sprake is, beklemtoon die belangrikheid dat daar nie sonder werklike gronde aanvaar moet word dat die ander voorskrifte in 2:8-15 op die erediens betrekking het nie.

\section{Die voorskrifte vir leer, onderrig en gesaguitoefening in 1 Timoteus 2:11-12}

Die voorskrifte in 2:11-12 word ondersoek deur eerstens aandag te gee aan Paulus se voorskrif hoe vroue moet leer. Daarna word Paulus se verbod om te onderrig en om oor die man gesag te voer, aan die orde gestel.

\subsection{Voorskrif om in stilte en onderdanigheid te leer in 1 Timoteus 2:11}

Wanneer die skrywer in 2:11 opdrag gee dat vroue in stilte en onderdanigheid moet leer, roep hy, volgens Ridderbos (1967:81-82), vroue op om nie in die erediens op die voorgrond te tree deur te praat nie. Hulle moet hul in die erediens laat leer. Die woord wat Paulus vir leer gebruik, te wete manqa nw, dui egter nie noodwendig daarop dat Paulus oor leer in die erediens skryf nie. Dit is uit Louw en Nida (1988a:327) duidelik dat daar uit die konteks waarbinne die woord manqanw gebruik word, afgelei moet word of inligting in 'n formele of informele situasie verkry word. Dit blyk dat Paulus in die brief 1 Timoteus wel die woord manqanw vir die verkryging van inligting in 'n informele situasie gebruik. Hy skryf van weduwees wat leer (manqanous in) om ledig rond te gaan (5:13) en van kinders wat moet leer (manqanetws $n$ ) om teenoor hulle eie huis eerbied te betoon (5:4). Daar kan dus nie aanvaar word dat Paulus noodwendig die woord manqanw in 2:11 vir die verkryging van inligting tydens die erediens gebruik nie.

Vroue moet volgens 2:11 in stilte (ej h $\$$ uc $i$ a ) en in onderdanigheid (ej pash/upotagh) leer. Groenewald (1977:37) lei uit die gebruik van die woord h $\$$ uc i a af dat vroue in Efese "aktief aan die erediens begin deelneem het" en dat Paulus volgens vers 11 met die woorde up ot a gh/en h $\mathrm{s} u \mathrm{ci}$ i vereis dat hierdie vroue tot orde geroep word. Die woord hsucia word egter nie net in die semantiese veld 
Kommunikasie, vir die betekenis om in 'n staat van stilte te wees aangewend nie (vgl. Louw \& Nida, 1988b:116). Paulus sou ook die woord in 2:11 in die semantiese veld Probleme, Verligting, Gunstige omstandighede, vir die betekenis 'n staat van onversteurbare stilte en kalmte kon gebruik (vgl Louw \& Nida, 1988a:247). Hiervolgens sou Paulus nie in 2:11 met sy verwysing na $h \xi u c i$ id van vroue vereis om nie te praat nie, maar dat hulle met 'n innerlike kalmte sal leer.

In 2:11 word nie gesê aan wie vroue onderdanig moet wees nie. Mounce (2000:119-120) noem verskeie moontlikhede, te wete dat van vroue verwag word om onderdanig te wees aan mans, leraars, die suiwer leer, die gemeente of ook die eietydse sosiale omstandighede. Dit val op dat Paulus in vers 12 vroue verbied om oor mans gesag uit te oefen. Wanneer gelet word op die noue verband tussen verse 11 en 12, kan aanvaar word dat hy in vers 11 onderdanigheid aan mans in gedagte het.

Die vraag is egter wie hierdie mans is aan wie vroue onderdanig moet wees. Indien daar in 2:8-15 oor gedrag in die erediens gehandel word en gelet word op wat Paulus in 2:12 sê, kan met Schreiner (1995:124) saamgestem word as hy sê: "Woman were to learn with entire submissiveness from men who had authority in the church and manifested that authority through their teaching."

Indien Paulus in vers 11 oor die gedrag van vroue in die gewone lewe handel, sou hy van vroue vereis om in hulle gewone lewe met innerlike kalmte en in onderdanigheid van mans te leer. Indien hierdie vers so geïnterpreteer word, sou dit baie moeilik wees om te verstaan wat Paulus se voorskrif presies behels. Hy sou sekerlik nie bedoel dat die gelowige vroue van Efese bereid moet wees om in alle omstandighede van alle mans te leer nie. Hy vermeld immers uitdruklik dat daar mans is wat 'n vals leer aangehang het (vgl. 1:20). Daar sou dus aanvaar moet word dat Paulus in 2:11 'n baie algemene voorskrif aan vroue gee en dat hy klem laat val op die gesindheid wat gelowige vroue teenoor mans openbaar. Waar mans in die gewone lewe instruksies gee, moet die gelowige vroue nie opstandig wees nie, maar onderdanig en innerlik kalm. Hulle moet die instruksies wat mans gee in hierdie gesindheid ontvang.

Indien Paulus in 2:8-15 vir mans en vroue voorskryf hoe hulle in die huwelik moet optree, sou hy volgens vers 11 van vroue verwag om met innerlike kalmte en in onderdanigheid van hulle mans te leer. Dit is moontlik dat hy in vers 11 die hoofskap van die man, wat hy in Efesiërs 5:23 uitdruklik vermeld, veronderstel en, soos in Efesiërs 
5:22 en 24, van die vroue sekere optrede in die lig van haar man se hoofskap verwag. In Efesiërs 5 omskryf Paulus die onderdanigheid van vroue, deur te sê hulle, soos wat die kerk aan Christus onderdanig is, aan hulle mans onderdanig moet wees. In die lig van die vals leer, wat volgens 1 Timoteus 4:3 aangaande die huwelik in daardie tyd in Efese verkondig is, sou Paulus die onderdanigheid van vroue aan hulle mans in 1 Timoteus 2 anders beskryf as in Efesiërs 5 . Hy beklemtoon hiervolgens dat vroue nie teen hulle mans opstandig moet wees nie, maar met innerlike kalmte en in alle onderdanigheid van hulle mans moet leer.

\subsection{Om te onderrig en gesag uit te oefen}

Volgens Schreiner (1995:113-114) en Mounce (2000:126) is dit duidelik dat vroue in 1 Timoteus 2:12 verbied word om in die erediens onderrig te gee (didaskein) en gesag uit te oefen (a uggent ein n). Daar word egter nie in vers 12 enige aanduiding gegee waar en wanneer vroue nie onderrig mag gee en gesag oor mans mag uitoefen nie (vgl. ook Okorie, 1988:102-103). Daar sou ook nie aanvaar kan word dat die skrywer deur die gebruik van die woord dida $\mathrm{kW}$ die erediens as plek van onderrig aandui nie. Louw en Nida (1988a:413) toon aan dat die woord dida s kw vir onderrig in 'n formele én informele situasie gebruik kan word.

Mounce (2000:42), Saucy (1994:86-91) en Towner (1989:215) wys daarop dat onderrig in die Pastorale Briewe 'n belangrike plek inneem. Timoteus word opdrag gegee om voort te gaan met sy onderrig (vgl. byvoorbeeld $1 \mathrm{Tim}$. 4:11 en 6:2). Betroubare mense moet uitgesoek word aan wie die onderrig toevertrou kan word (2 Tim. 2:2). Dit is 'n vereiste dat ouderlinge bekwaam moet wees om te onderrig (1 Tim. 3:2; vgl. ook 5:17). Dit is moontlik dat Paulus soms met die gebruik van dida $\mathrm{k}$ kW in 1 Timoteus na onderrig binne die erediens verwys, byvoorbeeld in 1 Timoteus $4: 11 ; 6: 2$ en 2 Timoteus 2:2. Wanneer hy egter in 3:2 van opsieners praat wat in staat moet wees om te onderrig, is dit duidelik dat hy nie na onderrig in die erediens verwys nie. Hy verwys na 'n opsiener wat in staat moet wees om rekenskap te kan gee van die leer (Ridderbos, 1976:90-91 en Guthrie, 1978:81). Daar kan dus nie uit Paulus se gebruik van die woord didas kw in die Pastorale Briewe afgelei word dat hy didas kw noodwendig in 1 Timoteus 2:12 vir onderrig in die erediens gebruik nie.

Paulus dui nie uitdruklik in 2:12 aan wie vroue nie mag onderrig nie. Omdat daar uit gedeeltes soos Titus 2:3-4 en 2 Timoteus 1:5 en 3:15 afgelei kan word dat die skrywer vroue nie totaal verbied om 
godsdienstige onderrig te gee nie (Barnett, 1989:231), sou aanvaar moet word dat Paulus nie vroue in 2:12 verbied om enige godsdienstige onderrig te gee nie. Die feit dat Paulus in 2:12 die gesagsuitoefening oor mans ter sprake bring, gee 'n aanduiding dat hy onderrig aan mans in gedagte het. Uit gedeeltes soos Handelinge 18:26 en Kolossense 3:16 is dit duidelik dat vroue wel in die tyd van die Nuwe Testament aan mans onderrig gegee het. Daar kan daarom aanvaar word dat Paulus vroue nie in die algemeen verbied om aan mans onderrig te gee nie, maar dat hy 'n spesifieke soort onderrig in gedagte het wat vroue nie aan mans mag gee nie. As ej pant $i$; topw in 2:8 na plekke waar die gemeente vir die erediens byeengekom het verwys (vgl. punt 4.2), is dit moontlik dat Paulus in 2:12 vroue verbied om tydens eredienste aan mans onderrig te gee.

Vir die doeleindes van hierdie artikel is dit belangrik om na te gaan of dit moontlik is dat Paulus met die verbod aan vroue om onderrig te gee, voorskrifte aan vroue gee vir hulle gedrag in die huwelik. Rengstorf (1973:138) wys daarop dat didaskw in die Nuwe Testament ook vir onderrig sonder enige godsdienstige verband gebruik kan word. Volgens Matteus 28:15 het die wagte, nadat aan hulle voorgesê is om die gerug te versprei dat die dissipels Jesus se liggaam gesteel het, gedoen het soos aan hulle geleer is (ejida v ghs a n). In Matteus 28:15 word die woord dus gebruik vir die betekenis voorskryf. Indien aanvaar word dat Paulus met sy voorskrif in 2:12 gedrag binne die huwelik in die oog het, is dit moontlik dat hy in 2:12 vroue verbied om aan hulle mans voor te skryf. In punt 6.1 is aangetoon dat dit moontlik is dat Paulus in 2:11 vroue oproep om in die huwelik hulle mans se hoofskap te erken, deur met ' $n$ innerlike kalmte en in alle onderdanigheid van hulle mans te leer. Indien Paulus in vers 12 vroue verbied om in die huwelik vir hulle mans voor te skryf, sou hierdie opdrag baie nóú aansluit by dit wat hy in vers 11 beveel. Volgens vers 11 moet vroue hulle mans se hoofskap erken deur met innerlike kalmte en in alle onderdanigheid van hulle mans te leer. In vers 12 word vroue verbied om hulle mans se hoofskap te misken, deur vir hulle mans voor te skryf.

Daar is reeds vermeld dat vroue in die tyd van die Nuwe Testament wel aan mans onderrig gegee het, byvoorbeeld Priscilla wat aan Apollos godsdienstige onderrig gegee het (Hand. 18:26). Die vraag ontstaan daarom of dit moontlik is dat Paulus in 2:12 vroue verbied om in die gewone lewe aan mans godsdienstige onderrig te gee. Dit sou, soos hier bo aangetoon, moontlik wees dat Paulus met 
dida k kw na die betekenis voorskryf verwys en dat Paulus vroue dus verbied om in die gewone lewe vir mans voor te skryf. Holmes (2000:90-95) wys daarop dat die skrywer in 2:12 die praesens infinitief van didaskw gebruik. Paulus sou dus spesifiek na 'n aanhoudende aksie kon verwys. Holmes (2000:91) aanvaar dat die skrywer nie in 2:12 onderrig in die erediens in die oog het nie, maar "something rather broader than 'teach" en dat die skrywer deur die praesens infinitief didaskein op 'n "continual instruction" wys. Wanneer die skrywer in 2:12 aan vroue voorskrifte gee vir die gewone lewe, verbied hy volgens Holmes (2000:94) "little else than 'going on and on', or 'nagging'". Volgens Holmes moet ajdrov" in 2:12 slegs met die infinitief a ugent ei h̀ verbind word en nie ook met didaskein nie. Vroue mag dus volgens hom nie vir "female relatives, slaves" of enigiemand voortdurend instruksies gee nie. Daar is reeds aangetoon dat daar in die lig van die verband tussen 2:11 en 2:12 eerder aanvaar moet word dat Paulus na onderrig van spesifiek mans verwys. Indien Paulus dus in 2:12 oor vroue se gedrag in die gewone lewe handel, sou aanvaar moet word dat hy vroue verbied om in die gewone lewe voortdurend besig te wees om vir mans voor te skryf.

Naas Paulus se verbod om onderrig te gee, wil Paulus ook nie dat die vrou oor die mans gesag uitoefen (a uggent eiǹ) nie. Verskeie pogings (vgl. byvoorbeeld Baldwin, 1995:65-80; Knight, 1984:143157; Pierce, 1993:349; Perriman, 1993:132-138 en Redekop, $1990: 242)$ is al aangewend om die betekenis waarvoor die woord a ugjent ew in 2:12 gebruik word, aan te dui. 6 Kroeger en Kroeger (1992:84-104) kom ná 'n studie van die godsdiens en kultuur van antieke Efese tot die gevolgtrekking dat die woord a ujgent ew in 1 Timoteus 2:12 vir die betekenis "to claim ownership, sovereignty, or authorship" gebruik word. Volgens hulle verbied die skrywer in 2:12 die vrou "[to] proclaim herself author of the man." (1992:103). Towner (1989:216) aanvaar ook dat a ugent ei h̀ in 2:11 na die uitoefening van gesag op 'n dwingende (dominerende) manier verwys. Hy sê dat die skrywer eerder die woord ejous i a sou gebruik as hy die uitoefening van gesag op 'n positiewe wyse in gedagte gehad het. Dit is egter duidelik dat Paulus a ugigent ein in 2:12 teenoor up ot a g h/in 2:11 stel. Daaruit blyk dat hy in 2:12 die vrou verbied om gesag uit te oefen oor die man en dat hy nie 'n dominerende wyse van gesaguitoefening in gedagte het nie (Schreiner, 1995:130). a ugent ew gebruik kan word. 
Köstenberger (1995:81-103) toon dat wanneer oujle;saam met twee infinitiewe gebruik word, die infinitiewe óf altwee positiewe óf altwee negatiewe aktiwiteite aandui. Omdat die infinitief didaskein 'n positiewe aktiwiteit aandui, ${ }^{2}$ sou ook aanvaar moet word dat hy met die infinitief a uggent ein' 'n positiewe aktiwiteit aandui.

Daar is reeds aandag gegee aan Paulus se verbod dat vroue nie mag leer nie en nie oor mans gesag mag uitoefen nie. Die vraag is egter hoe en of die verbod om te leer en die verbod om gesag uit te oefen met mekaar verband hou. Mounce (2000:130) toon oortuigend aan dat die skrywer met die verbod om gesag uit te oefen, 'n beginsel stel. Met die verbod aan vroue om te leer, gee hy 'n spesifieke toepassing van die beginsel. Indien hy in 2:12 oor die erediens handel, verbied hy vroue in beginsel om in die erediens oor mans gesag uit te oefen en pas hy die beginsel toe deur vroue te verbied om in die erediens gesag uit te oefen deur daar vir mans onderrig te gee. As hy in 2:12 vroue se gedrag in die gewone lewe in die oog het, verbied hy vroue in beginsel om in die gewone lewe voortdurend oor mans gesag uit te oefen. Hierdie beginsel pas hy toe deur hulle te verbied om voortdurend vir mans voor te skryf. Indien Paulus in 2:12 oor gedrag in die huwelik handel, stel hy die beginsel dat vroue nie oor hulle ${ }^{8}$ mans gesag mag uitoefen nie. Hierdie beginsel pas hy toe deur vroue te verbied om vir hulle mans voor te skryf.

\subsection{Gevolgtrekkings}

Uit die voorgaande is dit duidelik dat dit moontlik is dat Paulus in 2:11-12 voorskrifte gee vir gedrag in die erediens, die gewone lewe of die huwelik.

\section{Finale gevolgtrekkings}

- Paulus gee geen uitdruklike aanduidings in 1 Timoteus 2 van die konteks waarbinne die voorskrifte in 1 Timoteus 2:8-15 verstaan moet word nie.

7 Mounce (2000:124-126) toon oortuigend aan dat dit nie moontlik is dat dit in hierdie vers oor die verkondiging van 'n vals leer gaan nie.

$8 \quad$ Hugenberger (1992:353) toon uit gedeeltes soos Lukas 1:34; 2:36 en 1 Korintiërs 7:10 aan dat dit nie vir die skrywer noodsaaklik is om die besitlike voornaamwoord te gebruik indien hy van vroue se eie mans praat nie. 
- Dit is moontlik dat Paulus in 1 Timoteus 2 vir mans en vroue voorskrifte gee oor hulle gedrag in die erediens, die gewone lewe sowel as die huwelik. Dit het egter geblyk dat Paulus met sy voorskrifte vir kleredrag in 2:9-10 'n breër konteks as die erediens in 2:9-10 in die oog het. Daaruit blyk dat daar nie, soos dikwels gedoen word, sonder werklike gronde aanvaar kan word dat die ander voorskrifte in 2:8-15 op die erediens betrekking het nie.

- As Paulus in 2:8-15 voorskrifte vir die erediens in die oog het, kan die gedeelte soos volg verstaan word:

Paulus vereis volgens 2:8 dat mans sal sorg dat hulle van toorn en twis gereinig is voordat hulle op die plekke waar daar vir eredienste byeengekom word, bid. Nadat Paulus in 2:9-10 vir vroue voorskrifte gegee het hoe hulle hul in die algemeen moet versier, vereis hy in 2:11 dat vroue met innerlike kalmte en in alle onderdanigheid in die erediens sal leer van mans wat gesag ontvang het en daardie gesag uitoefen deur in die erediens te leer. Hy verbied vroue in 2:12 om in die erediens gesag uit te oefen oor mans, deur dáár aan mans onderrig te gee.

- Indien die vereistes in 2:8-15 in die konteks van die gewone lewe verstaan word, sou die gedeelte soos volg verstaan kan word:

Paulus vereis in 2:8 dat mans ten opsigte van hulle verantwoordelikhede in die gewone lewe gereinig moet wees van toorn en twis, sodat hulle kan bid. In 2:9-10 gee hy aan vroue voorskrifte hoe hulle hul in die gewone lewe moet versier en hy beklemtoon dat hulle hul nie seksueel verleidelik moet versier nie, en lê klem op die belangrikheid van goeie werke vir gelowige vroue. In 2:11 vereis Paulus van vroue om in die gewone lewe met innerlike kalmte en in alle onderdanigheid van mans te leer. Volgens 2:12 verbied hy vroue om in die gewone lewe oor mans gesag uit te oefen, deur voortdurend vir mans voor te skryf.

- As aanvaar word dat Paulus in 2:8-15 voorskrifte vir die huwelik gee, verwag hy die volgende van mans en vroue:

Mans moet hulle ten opsigte van hulle verantwoordelikhede teenoor hulle vroue reinig van toorn en twis - eers dan kan hulle bid (2:8).

Dit betaam getroude vroue nie om hulle seksueel uitlokkend te versier nie. Getroude vroue se versiering moet met beskeidenheid en ingetoënheid gepaard gaan. Paulus vereis verder van die gelowige vrou om haar man se hoofskap te erken, deur met 
innerlike kalmte en in onderdanigheid van hom te leer en nie oor hom gesag uit te oefen deur vir hom voor te skryf nie.

\section{Geraadpleegde bronne}

BALDWIN, H.S. 1995. A difficult word: A ugent ein in 1 Timothy 2:9-15. (In Köstenberger, A.J., Schreiner, T.R. \& Baldwin, H.S., eds. Woman in the church: a fresh analysis of 1 Timothy 2:9-15. Michigan: Baker Books. p. 65-80.)

BARNETT, P.W. 1989. Wifes and woman's ministry (1 Timothy 2:11-15). The Evangelical Quarterly, 61(1):225-238.

BREED. D.G. 1994. Die kenmotief in 2 Petrus: 'n eksegetiese studie. Potchefstroom: PU vir CHO. (Th.D.-proefskrif.)

BYBEL. 1933. Die Bybel: dit is die ganse Heilige Skrif wat al die kanonieke boeke van die Ou en die Nuwe Testament bevat. Kaapstad: Britse \& Buitelandse Bybelgenootskap.

BYBEL. 1983. Die Bybel: nuwe vertaling. Kaapstad: Bybelgenootskap van Suid Afrika.

CAIRNS, H.D. 1995. 1 Timothy 2:8-3:1: woman's ordination in the light of the Christian self-definition of woman in Ephesus. Pretoria: Unisa. (Master of arts - Biblical studies.)

COETZEE, J.C. 1988. Gedagtestruktuurontleding en die eksegese van die Heilige Skrifte. (In Coetzee, J.C., red. Koninkryk, Gees en Woord: huldigingsbundel aangebied aan prof. dr. Lambertus Floor by sy emeritaat as professor in die Nuwe Testament aan die Teologiese Skool, Potchefstroom en die Fakulteit Teologie van die Potchefstroomse Universiteit vir Christelike Hoër Onderwys. Pretoria: NG Kerkboekhandel. p. 19-37.)

CULLMAN, O. 1953. Early Christian worship. Philadelphia: Westminster.

DE KRUIJF, Th. C. 1966. De Pastorale brieven. Roermond: Romen.

DIBELIUS, M. \& CONZELMANN, H. 1972. A commentary on the Pastoral Epistles. Philadelphia: Fortress.

GROENEWALD, E.P. 1977. Die Pastorale Briewe. Kaapstad: NG KerkUitgewers.

GROSHEIDE, F.W. 1976. Commentary on the first epistle to the Corinthians. Grand Rapids: Eerdmans. (The International Commentary on the New Testament.)

GUTHRIE, D. 1978. The Pastoral Epistles. Grand Rapids: Eerdmans. (Tyndale New Testament Commentaries.)

HAHN, F. 1973. The worship of the early church. Philadelphia: Fortress.

HOLMES, J.M. 2000. Text in a whirlwind: a critique of four exegetical devices as 1 Timothy 2:9-15. Sheffield: Sheffield Academic Press.

HOWARD, J.K. 1983. Neither male nor female: an examination of the status of woman in the New Testament. Evangelical Quarterly, 55:31-42.

HUGENBERGER, G.P. 1992. Women in church office: hermeneutics or exegesis? A survey of approaches to 1 Tim. 2:8-15. Journal of the Evangelical Theological Society, 35(3):341-360.

KELLY, J.N.D. 1972. A commentary on the Pastoral Epistels. I and II Timothy, Titus. London: Black.

KNIGHT, G.W. 1984. A ugent ein in reference to woman in 1 Timothy 2.12. New Testament Studies, 30:143-157. 
KÖSTENBERGER, A.J. 1995. A complex sentence structure in 1 Timothy 2:12. (In Köstenberger, A.J., Schreiner, T.R. \& Baldwin, H.S., eds. Woman in the church: a fresh analysis of 1 Timothy 2:9-15. Michigan: Baker Books. p. 81-104.)

KROEGER, R.C. \& KROEGER, C.C. 1992. I suffer not a woman: rethinking 1 Timothy 2:11-15 in the light of ancient evidence. Michigan: Baker Book House.

LOUW, J. P. \& Nida, E.A. 1988a. Greek-English lexikon of the New Testament based on semantic domains. Vol. 1. New York: United Bible Societies.

LOUW, J. P. \& Nida, E.A. 1988b. Greek-English lexikon of the New Testament based on semantic domains. Vol. 2. New York: United Bible Societies.

MOULE, C.F.D. 1964. Worship in the New Testament. London: Lutterworth. (Ecumenical Studies in Worship, vol. 9.)

MOUNCE, W.D. 2000. Pastoral Epistles. Nashville: Thomas Nelson. (Word Biblical Commentary, vol. 46.)

OKORIE, A.M. 1988. Marriage in the Pastoral Epistles. Michigan: U.M.I. dissertation information service.

OSIEK, C. \& BALCH, L.B. 1997. Families in the New Testament world: households and house churches. Kentucky: Westminster John Knox.

PERRIMAN, A.C. 1993. What Eve did, what woman shouldn't do: the meaning of a uggent ein in 1 Timothy 2:12. Tyndale Bulletin, 44(1):129-142.

PIERCE, R.W. 1993. Evangelicals and gender roles in the 1990s: 1 Tim 2:8-15: a test case. Journal of the Evangelical Theological Society, 36(3):343-355.

REDEKOP, G.N. 1990. Let woman learn: 1 Timothy 2:8-15 reconsidered. Studies in Religion/ Sciences Religieuses, 19(2)234-245.

RENGSTORF, K.H. 1973. Didas kw. (In Kittel, G., ed. Theological Dictionary of the New Testament, 2:135-148.)

RIDDERBOS, D. 1967. De Pastorale Brieven. Kampen: N.V. Uitgeversmaatschappij. (Commentaar op het Nieuwe Testament.)

ROLOFF, J. 1988. Der erste Brief an Timotheus. Zurich: Benzinger.

SAUCY, R.L. 1994. Woman's prohibition to teach men: an investigation into its meaning and contemporary application. Journal of the Evangelical Theological Society, 37:79-97.

SCHOTTROFF, L. 1995. Lydia's impatient sisters: a feminist social history of early Christianity. Kentucky: WestminsterJohn Knox.

SCHREINER, T.R. 1995. An interpretation of 1 Timothy 2:9-15: a dialogue with scholarship. (In Köstenberger, A.J., Schreiner, T.R. \& Baldwin, H.S., eds. Woman in the church: a fresh analysis of 1 Timothy 2:9-15. Michigan: Baker Books. p. 105-154.)

TOWNER, P.H. 1989. The goal of our instruction: the structure of the theology and ethics in the Pastoral Epistles. Sheffield: Sheffield Academic Press.

VERNER, C.V. 1983. The household of God: the social world of the Pastoral Epistles. California: Scholars Press.

\section{Kernbegrippe:}

\section{Timoteus 2}

huwelik

openbare erediens

vroue 
Key concepts:

1 Timothy 2

marriage

public worship

woman 
